\title{
Efektivitas Model OPPEMEI untuk Meningkatkan Kemampuan Berpikir Kreatif Mahasiswa
}

\author{
I Gusti Ayu Tri Agustiana \\ Program Studi Pendidikan Guru sekolah Dasar, FIP, Undiksha, Singaraja, Indonesia \\ Email: igustiayutriagustiana@yahoo.co.id \\ Rudiana Agustini \\ Chemistry Education of Department, State University of Surabaya \\ Email: rudiana.agustini@gmail.com \\ Musimin Ibrahim \\ Biology Education of Department, Stat University of Surabaya \\ Email: muslimin.ibr@gmail.com
}

I Nyoman Tika

Program Studi penidikan Dasar Pasca Sarjana Unidksha, Singaraja, Indonesia Email:nyomanntika@gmail.com

\author{
A R T I C L E I N F O \\ Article history: \\ 1 Maret 2020 Received in \\ revised form \\ 30 Maret 2020 \\ Accepted 11 April 2020 \\ Available online 15 \\ Mei 2020 \\ Kata Kunci: \\ Berfikir Kreatif, \\ OPPEMAI, \\ Mahasiswa \\ Keywords: \\ Creative thinking, \\ OPPEMEI, students
}

\begin{abstract}
A B S T R A K
Tujuan penelitian ini untuk peningkatan kreativitas dan hasil belajar mahasiswa pada mata kuliah konsep dasar IPA di Jurusan PGSD, dengan menggunakan model baru pembelajaran OPPEMEI, dengan rancangan tahap-tahap pembelajaran meliputi tahap orientasi, penggalian ide, penelitian, elaborasi, memamerkan hasil karya dan implementasi. Penelitian ini menggunakan pendekatan deskriptif kualitatif untuk jenis penelitian tindakan. Subyek penelitian ini 4 kelas (kelas F, G,B,dan A). Metode pengumpulan data menggunakan tes keterampilan berpikir kreatif dengan indikator kemampuan berpikir kreatif terdiri berpikir lancar (fluency), berpikir luwes (flexibility), berpikir terperinci (elaboration), berpikir orisinil (originality). Peningkatan kemampuan berpikir kreatif dianalisis $\mathrm{N}$-gain. Hasil penelitian menunjukkan bahwa peningkatan rata-rata $\mathrm{N}$-gains dari kemampuan berpikir kreatif, sebesar 0,27, 0,153 dan 0,101, peningkatan terjadi pada kelas F. Indikator keterampilan berpikir kreatif yang paling tinggi adalah fluency, atau kelancaran $\mathrm{N}$-gain sebesar 0,67 dengan kriteria sangat tinggi mahasiswa berpikir lancar dengan materi dan perubahannya dalam bentuk model gunung meletus. Hal ini menunjukkan bahwa model pembelajaran OPPEMEI meningkatkan kemampuan berpikir kreatif yang nantinya akan memepengaruhi hasil
\end{abstract} belajar mahasiswa. Dengan adanya model OPEMEI ini akan menjadi salah satu solusi dalam proses pembelajaran khususnya dalam penggunaan model pembelajaran.

\begin{abstract}
A B S T R A C T
The purpose of this research was to improve the students' creativity and learning outcomes in basic natural science concept course in PGSD Department by using OPPEMEI, it was a new learning model consisted with the steps of learning, such as the orientation, exploration, research, elaboration, exhibition, and implementation. This research used a qualitative descriptive analysis. The subjects of this research were 4 classes (classes $F, G, B$, and A). Data collection method used creative thinking skills tests with indicators of creative thinking ability which was consisted of fluency, flexibility, elaboration, and originality. Creative thinking skill ability improvement was analyzed by using $N$-gain. The results showed that there was an improvement in average score of $N$-gains from the creative thinking skills in the amount of 0.27, 0.153 and 0.101, an improvement occurred in class $F$. The highest indicator of creative thinking skills was fluency of $N$-gain in the amount of 0.67. It was categorized into very high criteria. This research showed that the OPPEMEI learning model improved the creative thinking skill ability which would affect the students' learning outcomes. OPEMEI model would be one of the solutions in the learning process especially in the use of learning models.
\end{abstract}

\section{Pendahuluan}

Berpikir kreatif sangat penting dalam pembelajaran abad 21. Berpikir kreatif salah satunya dapat diwujudkan melalui pembelajaran sains. Oleh sebab itu saat ini sains berkembang sangat pesat, khususnya dalam mengembangkan keterampilan kognitif tingkat tinggi mahasiswa (higher-order cognitive skills, HOCS), sebagai lawan dari pendekatan tradisional, yang hanya berbasis algoritma lower-order keterampilan kognitif (Casagrand and Semsar, 2017). Pembelajaran sains merupakan salah satu cabang ilmu yang membutuhkan 
keterampilan kognitif tingkat tinggi, yang bertujuan membangun kerangka konseptual dan keterampilan proses, sehingga membangun kreativitas berpikir tingkat tinggi dan berpikir kritis(Jatmiko, et al., 2018).

Berbagai masalah dalam pembelajaran sains dapat diatasi dengan memberikan tantangan bagi peserta didik untuk melatih rasa tanggung jawab dan kreativitas ilmiah (Suyidno, et al., 2018; Yu, Brown and Farnworth, 2017). Pendidikan sains mempersiapkan peserta didik untuk memiliki pemahaman tentang sains dan teknologi, melalui pengembangan keterampilan berpikir, sikap dan keterampilan dalam upaya untuk memahami dirinya sehingga dapat mengelola lingkungan, dapat mengatasi masalah dalam lingkungannya (Bas, 2012). Oleh karena itu tingkat pemahaman kognitif dan keterampilan berpikir kreatif sesuai dengan karakterisitik dan hakikat sains menjadi sangat penting (Blass et al., 2016). Selain itu, perekrutan mahasiswa Pendidikan Guru Sekolah Dasar Universitas Pendidikan Ganesha berasal dari berbagai jurusan di Sekolah menengah Atas (SMA) dan Sekolah menengah Kejuruan (SMK) yakni bahasa, ilmu pengetahuan Sosial (IPS) dan Sains, kondisi ini sangat menyulitkan proses pembelajarn kemampuan sains. Kondisi ini sekaligus tidak membuat pembelajaran yang kreatif dan inovatif. Latar belakang mahasiswa sangat mempengaruhi kreativitas berpikir mahasiswa (Suzan et. al., 2013).

Berbagai upaya intervensi oleh para ahli pendidikan dalam memudahkan pemahaman konsep sains telah dilakukan untuk membangun keterampilan berpikir kreatif pada mahasiswa calon guru, yakni: menggunakan model pengajaran inkuiri (Artayasa et al., 2016: Akkuzu \& Uyulgan, 2016), Lewat model bercerita (Storytelling model) (Peleg et al., 2009), Model teka teki silang (Crossword Puzzle) (Yuriev, Capuano and Short, 2016), case-based learning instruction (Çam and Geban, 2017), Purdue Model (Şener and Taş, 2017), pendekatan sains yang ramah lingkungan (Haack and Hutchison, 2016). STAD untuk pembelajaran sains (Gencosman, 2012). Penggunaan berbagai model dan pendekatan itu masih menunjukkan bahwa mahasiswa memiliki hambatan dalam memahami konten dan proses sains. Hal ini didasarkan bahwa sains adalah subjek kompleks yang memiliki banyak konsep abstrak dan sering kontra intuitif (Gabel,1998). Selanjutnya, Hawkes (1996) dan yang lainnya (Wahyuni (2017); Fadillah (2013) mengemukakan bahwa hambatan psikologis pada mahasiswa terjadi pada aspek memahami tabir fenomena alam, yang muncul karena perubahan yang demikian cepat dalam teknologi informasi dalam pembelajaran sains, sehingga membutuhkan kemampuan keterampilan berpikir kreatif (Fang et al., 2016).

Kemampuan berpikir kreatif dengan laju perubahan infomasi sejalan dengan konsep Marinacci, (1996) sebagai the scientific methode of logical thinking. Dalam koridor scientific methode membutuhkan setting reformasi pembelajaran dan pengajaran, yang senafas dengan Adaptive Control Of Thought-Rational (ACT-R) Anderson (2002), dan telah terbukti bahwa scientific methods sesuai dengan teori perkembangan kognitif Piaget, bahwa keterampilan berpikir kreatif dapat diadaptasikan lebih baik di kelas-kelas awal (Barrouillet, 2015). Intervensi untuk memicu kemampuan berpikir kreatif yang baik, dapat dimulai dari pembelajaran IPA di SD (Agustiana, 2009). Hasil belajar IPA siswa-siswa SD relatif rendah, disebabkan oleh beberapa faktor, yakni pertama, penggunaan metode mengajar guru yang kurang tepat, sehingga siswa hanya menghafal bukan memahami materi (Agustiana, 2015). Kedua, kemampuan guru memotivasi anak masih rendah (Hagger and Chatzisarantis, 2016), sehingga pendekatan baru perlu digagas untuk pembelajaran calon guru SD. Ketiga, terjadinya miskonsepsi, karena belum bisa berpikir abstraksi(Sadler and Sonnert, 2016). Kemampuan berpikir kreatif berkorelasi positif dengan hasil belajar IPA calon guru (Adele et al., 2010). Pada perkuliahan konsep Dasar IPA, terlihat kemampuan berpikir kreatif mahasiswa PGSD relatif rendah khususnya yang berkaitan dengan konsep-konsep kimia (Agustiana, 2015). Pada konteks itu prinsip-prinsip pembelajaran sains (IPA), khusus konsep dasar IPA bagi mahasiswa calon guru, menarik untuk dibenahi lewat suatu model yang khsusus mampu mengungkap dan memberikan kemampuan berpikir kreatif bagi mahasiswa calon guru SD.

Model OPPEMEI merupakan salah satu model pembelajaran untuk meningkatkan kreativitas peserta didik. Sehingga partisipasi differensial akan terlihat nyata. Partisipasi differensial dapat menggambarkan dan menjelaskan penyebab mendasar dari tingkat partisipasi diferensial dalam bidang-bidang tertentu, dan kami mendiskusikan arah utama untuk penelitian di masa depan (Demontis, D. et al., 2019). Model pembelajaran OPPEMEI membangun berpikir kreatif (Agustiana, et al., 2018) menjadi sangat relevan untuk diterapkan dalam pembelajaran konsep dasar IPA, karena memiliki sintak dengan sasaran (1) fokus orientasi pada tahap awal pembelajaran, (2) adanya penggalian ide-ide yang menantang kognitif mahasiswa, (3) aspek penyelidikan untuk pemecahan masalah kreatif, (4) aspek saling tukar menukar ide (elaborasi), (5) aspek mengembangkan dan menghasilkan karya, (6) aspek evaluasi sebagai refleksi serta revisi, dan terakhir (7) aspek implementasi (Agustina, Agustini R, Ibrahim, M, 2017) .

Model pembelajaran OPPEMEI diekstrak dari tiga model pembelajaran inovatif berpusat pada mahasiswa seperti PBL, BBL dan inquiri. Formulasi berpikir kreatif peserta didik merupakan inti yang dikembangkan dari model OPPEMEI. Kondisi ini didasari bahwa model pembelajaran untuk sains selalu berangkat pada model pembelajaran 5M (Mengamati, Menanya, Mencoba, Menalar, dan Mengkomunikasikan). Oleh karena Model pembelajaran yang mampu menghasilkan berpikir kreatif sesungguhnya adalah penerapan pendekatan pembelajaran saintifik, meniscayakan kehadiran guru yang tidak 
saja sabar dan telaten, tetapi juga cerdas dan kreatif berkolaborasi dengan peserta didik untuk menciptakan kondisi pembelajaran yang memungkinkan mereka mampu merumuskan masalah dengan baik. Para guru/dosen diharapkan mampu menfasilitasi peserta didik berlatih berfikir analitis, bukan berpikir mekanis.

Pendekatan saintifik juga terlihat pada tahapan Model OPPEMEI yang terdiri : (1) orientasi, (2) penggalian ide kreatif, (3) penyelidikan (investigasi), (4) elaborasi, (5) menyajikan hasil karya, (6) evaluasi, dan (7) implementasi. Penggunaan model ini berangkat dari teori motivasi kognisi, teori ini percaya bahwa individu terdorong untuk melaksanakan tindakan dari pemikirannya bila diberikan stimulus dengan berbagai masalah yang kontekstual, sehingga terkonstruksi pemahaman yang lebih mendalam. Selain itu kontruksi keterampilan berpikir kreatif juga dapat dimunculkan dengan baik.

Selain itu, karakteristik model OPPEMEI meliputi : (a) Keluwesan dapat dilakukan dengan memberikan orientasi terstruktur pada peserta didik, sehingga memberikan stimulus pada kinerja otaknya, untuk dapat berpikir asosiasi sehingga melahirkan ide-ide baru, yang merupakan produk berpikir kreatif. (b) Kebaruan ide, pada kemampuan berpikir peserta didik, membutuhkan ruang untuk menggali ide-ide baru. Ideide baru dapat terjadi apabila memberikan sebuah permasalahan, sehingga menghasilkan kondisi konflik kognitif pada diri peserta didik, (c) Setelah memperoleh ide/gagasan dibutuhkan pengujian untuk memperoleh data dengan melakukan penyelidikan. (d) Munculnya ide baru, yang merupakan hasil dari berpikir kreatif membutuhkan kondisi untuk peserta didik mengolah masukan ide dari berbagai sumber, kondisi ini membutuhkan fase elaborasi pada tahap pembelajaran, (e) Hasil dari penyelidikan memerlukan tahap untuk menyajikan hasil karya, (f) Ide gagasan yang disajikan membutuhkan evaluasi, sehingga ada umpan balik untuk memantapkan ide/gagasan, yang dihasilkan dari proses berpikir kreatif. (g) Masukan-masukan yang didapat membutuhkan penguatan, sehingga membutuhkan pengintegrasian untuk diimplementasikan agar terjadi proses internalisasi pada diri peserta didik.

Kebaruan model OPPEMEI dibandingkan model pembelajaran model Inovatif dan kreatif lainnya adalah (1) dapat membangun kemampuan untuk berpikir lancar (fluency), sehingga terfokus dan meningkatkan rasa ingin tahu dan senang dalam memecahkan masalah sains, (2) Peserta didik dapat memiliki motivasi intrinsik secara tepat serta rasa percaya diri dalam proses pembelajaran, (3) Membangun cara berpikir original (asli) dalam menyelidiki suatu permasalahan, sehingga mudah merumuskan hipotesis serta pikiran terbuka terhadap berbagai situasi serta mampu membuat gambaran mental terhadap masalah yang dihadapi, (4) Mengembangkan dan memperluas suatu gagasan baru (originalitas), serta dapat menjelaskan secara rinci /mendetail serta mampu memberikan argumentasi ilmiah dengan mengkonstruksi teori dari berbagai sumber pengetahuan, (5) Mahasiswa memiliki kemampuan berpikir yang luwes untuk mempertahankan dan menerima pendapat. (6) Mahasiswa mampu mengoptimal penguasaan konsep dan kemampuan berpikir kreatif nya, sehingga melahirkan rasa senang dan mencintai proses belajar pada diri mahasiswa. (7) Mahasiswa mampu menilai dan membuat masalah baru setelah melaksanankan pembelajaran.

Berdasarkan masalah serta jabaran tentang model OPPEMEI, maka perlu dilakukan kajian lebih dalam terhadap efektivitas model pembelajaran OPPEMEI terhadap kemampuan berpikir kreatif mahasiswa Pendidikan Guru sekolah Dasar (PGSD) Universitas pendidikan Ganesha, untuk mata kuliah konsep dasar IPA, untuk topik materi-materi perubahan.

\section{Metode}

Penelitian ini menggunakan pendekatan kualitatif. Jenis penelitian yang digunakan adalah Penelitian Tindakan, yaitu penelitian yang dilakukan oleh dosen dengan tujuan untuk memecahkan masalah yang terjadi di kelas/ruang kuliah selama proses pembelajaran terjadi atau meningkatkan kualitas pembelajaran di kelas. Langkah pertama yang dilakukan dalam penelitian ini adalah untuk melakukan rencana tindakan pra-penelitian, yaitu peneliti melakukan pengamatan sebelum penelitian dilakukan. Pengamatan ini bertujuan untuk meninjau tempat, untuk mengetahui kemauan kampus untuk melayani sebagai tempat studi, dan untuk mengamati lebih dekat daerah atau tempat studi dan untuk melakukan izin belajar, untuk bertemu dosen tutor untuk menentukan jadwal penelitian dan mulai observasi, dan siapkan semua dokumen yang diperlukan pada saat itu dari penelitian. Langkah selanjutnya dalam penelitian ini adalah peneliti mengambil tindakan-tindakan pada siklus pertama dikelas F: melaksanakan tindakan, tindakan observasi, dan refleksi tindakan, karena jenis penelitian ini adalah penelitian tindakan yang memberi umpan pada aktivitas yang dilakukan oleh penelitian yang berarti bahwa jika siklus pertama terasa diinginkan, peningkatannya masih kurang sehingga dosen atau peneliti dapat menerapkan tindakan yang sama sebagai perbaikan implementasi dalam siklus kedua di kelas $\mathrm{B}$, selanjutnya dikelas $\mathrm{C}$, dan terkahir A.

Penelitian ini dilakukan di Prodi Pendidikan Guru Sekolah Dasar, Fakultas Ilmu Pendidikan, Universitas Pendidikan Ganesha, dengan subjek penelitian adalah mahasiswa semester ketiga yang berjumlah 134 siswa yang terdiri dari 68 mahasiwa laki-laki dan 66 mahasiswa perempuan. Teknik pengumpulan data menggunakan 
instrumen penelitian sebagai berikut adalah pertanyaan tentang tes, wawancara, observasi, catatan lapangan, dan dokumentasi. Tes yang digunakan dalam penelitian ini adalah tes pilihan dan memiliki uji validitas data dengan melakukan tes instrumen, dimana tes pertanyaan dapat digunakan jika mereka telah lulus uji validitas, uji reliabilitas, tes tingkat kesulitan dan uji kekuatan yang berbeda. Jika ada pertanyaan dari 4 tes dengan baik maka masalah baru dapat diberikan kepada siswa untuk digunakan sebagai satu instrumen dalam penelitian.

Tes keterampilan berpikir kreatif berfungsi untuk mengetahui kemampuan mahasiswa dalam memecahkan masalah-masalah sains. Tes keterampilan berpikir kreatif diberikan sekali yaitu sebagai post test. Kriteria penilaian tes kemampuan pemecahan masalah menggunakan rubrik penilaian pada Tabel 1.

Tabel 1 Rubrik Penilaian Keterampilan Berpikir Kreatif

\begin{tabular}{|c|c|c|c|}
\hline Dimensi Soal & No Soal & Skor & Karakteristik \\
\hline \multirow[t]{4}{*}{$\begin{array}{l}\text { Berpikir Lancar } \\
\text { (Fluency) }\end{array}$} & 1 & 3 & $\begin{array}{l}\text { - Jawaban yang dihasilkan dua cara yang berbeda dengan diberi } \\
\text { penjelasan dan gambar } \\
\text { - Jawaban berdasarkan wacana dan teori yang ada } \\
\text { - Dirumuskan dalam bahasan yang runut dengan bahasa yang baik dan } \\
\text { benar. }\end{array}$ \\
\hline & & 2 & $\begin{array}{l}\text { - Jawaban yang dihasilkan satu cara dengan diberi penjelasan dan } \\
\text { gambar } \\
\text { - Jawaban berdasarkan wacana dan teori yang ada } \\
\text { - Dirumuskan dalam bahasan yang runut dengan bahasa yang baik dan } \\
\text { benar. }\end{array}$ \\
\hline & & 1 & $\begin{array}{l}\text { - Jawaban yang dihasilkan satu cara dengan tidak diberi penjelasan } \\
\text { dan gambar } \\
\text { - Dirumuskan dalam bahasan yang kurang runut dengan bahasa yang } \\
\text { kurang baik }\end{array}$ \\
\hline & & 0 & - $\quad$ Tidak menjawab atau jawaban salah \\
\hline \multirow[t]{4}{*}{$\begin{array}{l}\text { Berpikir Luwes } \\
\text { (Flexibility) }\end{array}$} & 2,4 & 3 & $\begin{array}{l}\text { - Jawaban yang dihasilkan dua variasi disertai dengan penjelasan } \\
\text { - Jawaban berdasarkan wacana dan teori yang ada } \\
\text { - Dirumuskan dalam bahasan yang runut dengan bahasa yang baik dan } \\
\text { benar. }\end{array}$ \\
\hline & & 2 & $\begin{array}{l}\text { - Jawaban yang dihasilkan dua variasi tidak disertai dengan penjelasan } \\
\text { - Jawaban berdasarkan wacana dan teori yang ada } \\
\text { - Dirumuskan dalam bahasan yang runut dengan bahasa yang baik dan } \\
\text { benar. }\end{array}$ \\
\hline & & 1 & $\begin{array}{l}\text { - Jawaban yang dihasilkan satu variasi disertai dengan penjelasan } \\
\text { - Dirumuskan dalam bahasan yang kurang runut dengan bahasa yang } \\
\text { kurang baik }\end{array}$ \\
\hline & & 0 & - $\quad$ Tidak menjawab atau jawaban salah \\
\hline \multirow[t]{4}{*}{$\begin{array}{l}\text { Berpikir } \\
\text { Terperinci } \\
\text { (Elaboration) }\end{array}$} & 5,6 & 3 & $\begin{array}{l}\text { - Jawaban yang dihasilkan detail dan terperinci dengan disertai } \\
\text { penjelasan yang logis } \\
\text { - Jawaban berdasarkan wacana dan teori yang ada } \\
\text { - Dirumuskan dalam bahasan yang runut dengan bahasa yang baik dan } \\
\text { benar. }\end{array}$ \\
\hline & & 2 & $\begin{array}{l}\text { - Jawaban yang dihasilkan tidak detail dan rinci tetapi disertai } \\
\text { penjelasan } \\
\text { - Jawaban berdasarkan wacana dan teori yang ada } \\
\text { - Dirumuskan dalam bahasan yang runut dengan bahasa yang baik dan } \\
\text { benar. }\end{array}$ \\
\hline & & 1 & $\begin{array}{l}\text { - Jawaban yang dihasilkan tidak detail dan rinci tanpa disertai } \\
\text { penjelasan } \\
\text { - Dirumuskan dalam bahasan yang kurang runut dengan bahasa yang } \\
\text { kurang baik }\end{array}$ \\
\hline & & 0 & - $\quad$ Tidak menjawab atau jawaban salah \\
\hline \multirow[t]{2}{*}{$\begin{array}{l}\text { Berpikir Orisinil } \\
\text { (Originality) }\end{array}$} & 3 & 3 & $\begin{array}{l}\text { - Jawaban yang dihasilkan original dengan diberikan penjelasan dan } \\
\text { gambar } \\
\text { - Jawaban berdasarkan wacana dan teori yang ada } \\
\text { - Dirumuskan dalam bahasan yang runut dengan bahasa yang baik dan } \\
\text { benar. }\end{array}$ \\
\hline & & 2 & $\begin{array}{l}\text { - Jawaban yang dihasilkan original tanpa diberikan penjelasan dan } \\
\text { gambar } \\
\text { - Jawaban berdasarkan wacana dan teori yang ada }\end{array}$ \\
\hline
\end{tabular}


- $\quad$ Dirumuskan dalam bahasan yang runut dengan bahasa yang baik dan benar.

\begin{tabular}{lll} 
& & benar. \\
\hline 1 & $\bullet$ & Jawaban yang dihasilkan tidak original dan sesuai dengan teori yang \\
ada & \\
& $\bullet$ & $\begin{array}{l}\text { Dirumuskan dalam bahasan yang kurang runut dengan bahasa yang } \\
\text { kurang baik }\end{array}$ \\
\hline 0 & $\bullet$ & Tidak menjawab atau jawaban salah \\
\hline
\end{tabular}

\section{Hasil dan Pembahasan}

Hasil kreativitas mahasiswa dari analisis data dan hasil belajar siswa dalam ranah kognitif dapat dilihat bahwa pada siklus pertama, bahwa tingkat penguasaan konsep dalam bentuk hasil belajar mahasiswa semester III pada semester genap, untuk mata kuliah konsep dasar IPA belum sesuai dengan yang diharapkan, rata-rata nilai belum tuntas. Data selengkapnya dapat dilihat pada tabel 4.1 Pada siklus pertama, dengan materi perubahan materi gunung meletus, pre-test diikuti oleh 134 mahasiswa, dengan rincian 66 perempuan dan 68 laki-laki. Nilai pre-test 66 mahasiswa masih belum ada yang lengkap dan belum ada yang mencapai standar kelulusan.

Tabel 2. Perbandingan hasil keterampilan berpikir kreatif dengan pembelajaran model OPPEMEI di kelas F, C, B dan kelas A

\begin{tabular}{|c|c|c|c|c|c|c|}
\hline \multirow{2}{*}{ Indikator KBK } & \multicolumn{4}{|c|}{ Keterampilan Berpikir Kreatif } & \multirow{2}{*}{$N$-gain } & \multirow{2}{*}{ Kriteria } \\
\hline & Kelas F & Kelas C & Kelas B & Kelas A & & \\
\hline Fluency & 1.43 & 1.94 & 2.43 & 2.48 & 0.67 & Tinggi \\
\hline Flexibility & 0.74 & 1.45 & 1.73 & 1.84 & 0.49 & Sedang \\
\hline Originality & 0.23 & 0.46 & 0.54 & 0.88 & 0.36 & Sedang \\
\hline Elaboration & 0.75 & 1.42 & 1.67 & 1.69 & 0.42 & Sedang \\
\hline Evaluation & 0.53 & 1.46 & 1.63 & 1.82 & 0.52 & Sedang \\
\hline Rerata & 0.73 & 1.34 & 1.60 & 1.74 & & \\
\hline Kriteria & TB & B & B & B & & \\
\hline$N$-gain & \multicolumn{2}{|c|}{0.27} & 0.153 & 0.101 & & \\
\hline
\end{tabular}

Sebagaimana ditunjukkan pada Tabel 1. kualitas pembelajaran mengalami peningkatan kemampuan berpikir kreatif. Berdasarkan skor yang diperoleh dari pengamatan terhadap pembelajaran yang dilaksanakan oleh dosen mitra dikelas uji coba yakni kelas F, C, B, dan A, menunjukkan peningkatan rata-rata $\mathrm{N}$-gains dari kemampuan berpikir kreatif, sebesar LKM1, yakni sebesar 0,27, 0,153 dan 0,101. Penigkatan terjadi pada kelas F. Indikator keterampilan berpikir kreatif yang paling tinggi adalah fluency, atau kelancaran N-gain sebesar 0,67 dengan kreteria sangat tinggi (gambar 4.5), Artinya mahasiswa berpikir lancar sudah terjadi pada pertemuan pertama, dengan LKM-1 dengan materi dan perubahannya dalam bentuk model gunung meletus. Kelas F, siklus I aktivitas mahasiswa sebesar 59,94\%, di siklus II menjadi 64,62, siklus III menjadi 69,01\% dan siklus IV menjadi $76,32 \%$. Aktiviatas tertinggi adalah pada aspek melakukan eksperimen. Mahasiswa tampak antusias ketika melakukan penyelidikan atau percobaan. Untuk kelas C, siklus I aktivitas mahasiswa sebesar 40,06\%, di siklus II menjadi 70,16, siklus III menjadi 74,60\% dan siklus IV menjadi 82,22\%. Aktivitas tertinggi di kelas $\mathrm{C}$ adalah pada aspek melakukan eksperimen. Mahasiswa tampak antusias juga ketika melakukan penyelidikan atau percobaan. Untuk kelas B, siklus I aktivitas mahasiswa sebesar 69,28\%, di siklus II menjadi 77,45, siklus III menjadi $82,60 \%$ dan siklus IV menjadi $84,64 \%$. Aktivitas tertinggi di kelas B adalah pada aspek melakukan eksperimen. Mahasiswa juga tampak antusias ketika melakukan penyelidikan atau percobaan. Di kelas B adalah pada aspek bertanya dalam fase orientasi. Mahasiswa juga tampak antusias ketika melakukan penyelidikan atau percobaan.

Kemampuan berpikir kreatif dan penguasaan pengetahuan secara kognitif mahasiswa muncul setelah mengikuti proses belajar mengajar. Dalam menguji keefektifan model pembelajaran OPPEMEI, pada tahap uji coba dibagi dalam dua katagori, yaitu, (a) kemampuan keterampilan berpikir kreatif dan, (b) kemampuan kognitif (hasil belajar kognitif) mahasiswa. Dalam uji coba ini dilakukan dalam 4 kelas yaitu kelas F, C, B, dan A mahasiswa semester 3 Jurusan PGSD FIP, Universitas Pendidikan Ganesha.

Dari gambaran di atas dapat dijelaskan bahwa, model pembelajaran OPPEMEI dibutuhkan sebagai model menghadapi tantangan dalam diri seseorang siswa. Memahami ketidak setaraan berbasis kelompok dalam pendidikan membutuhkan perhatian tidak hanya pada kinerja dan hasil pencapaian, tetapi juga tentang bagaiamana siswa mempertahankan motivasi untuk jalur pendidikan dan karier mereka dalam jangka waktu yang 
lama. Model self-regulation of motivasi (SRM) menggambarkan bagaimana pilihan siswa untuk bertahan didorong oleh interaksi dinamis antara motivasi yang ditentukan tujuan, yang biasanya memandu pilihan untuk memulai atau terlibat kembali dalam suatu kegiatan, dan motivasi yang ditentukan pengalaman (atau minat), yang menjadi prediktor kegigihan proksimal setelah terlibat dalam aktivitas. Pengaruh sosial dapat membentuk kedua jenis motivasi dengan cara yang secara sistematis berkontribusi pada perbedaan dalam kegigihan siswa lintas kelompok dan bagaimana orang mengatur motivasi. Model OPPEMEI memungkinkan untuk merinci cara dimana peran sosial dan norma kelompok, antar pribadi, dan hambatan struktural kelembagaan dapat membentuk pengalaman motivasi dan kegigihan kelompok siswa yang kurang terwakili melalui beberapa proses tertentu dalam model OPPEMEI.

Motivasi ekstrinsik merupakan motivasi yang berasal dari luar atau rangsangan yang didapatkan seseorang dari luar. Motivasi ini muncul karena seseorang yang ingin mendapatkan sesuatu karena perintah orang lain. Misalnya saja seorang siswa harus belajar lebih giat untuk mendapatkan nilai bagus karena akan mengikuti ujian. Mereka terdorong untuk belajar bukan karena keinginan mendapatkan ilmu namun karena keinginan untuk mendapatkan nilai yang bagus. Investigasi ini mengevaluasi sejauh mana pelatihan kreativitas, instruksi pembuatan ide, dan proses kreatif memengaruhi produksi ide, kreativitas solusi, dan efektivitas kepemimpinan. Tiga set hipotesis diuji dengan 114 kelompok orang dewasa. Pertama, kelompok-kelompok yang anggotanya memiliki beberapa (yaitu, satu kursus CPS) atau pelatihan lanjutan (yaitu, studi tingkat pascasarjana di bidang kreativitas atau profesional kreativitas) secara signifikan lebih efektif pada pembuatan ide daripada kelompok tanpa pelatihan. Selain itu, para pemimpin dengan beberapa dan pelatihan lanjutan dianggap secara signifikan lebih efektif daripada mereka yang tidak memiliki pelatihan kreativitas. Sehubungan dengan kreatifitas solusi, semua kelompok pelatihan lanjutan mengungguli yang lain. Set hipotesis kedua berfokus pada keefektifan instruksi pembuatan ide (yaitu, instruksi tanpa brainstorming, brainstorming, dan brainstorming dengan kritik). Analisis mengungkapkan tidak ada perbedaan yang signifikan untuk instruksi pembuatan ide relatif terhadap produksi ide atau kreativitas solusi. Set hipotesis terakhir meneliti penggunaan struktur proses sederhana untuk kelompok tanpa pelatihan kreativitas sebelumnya (yaitu, fase berbeda untuk pembuatan ide dan pengembangan solusi). Analisis mengungkapkan bahwa pertemuan-pertemuan yang mengikuti struktur proses sederhana dilakukan kelompok yang tidak mengikuti proses untuk generasi ide dan kreativitas solusi.

Kreativitas berawal dari berpikir kreatif. Kemampuan berpikir kreatif mengacu pada sebuah konsep dari aktivitas mental untuk membuat hubungan-hubungan (conections) yang terus menerus (kontinu), sehingga dihasilkan produk assosiasi berpikir yang tepat (Evans, 1991), yang pada prinsipnya adalah sejalan dengan hal tersebut di atas Munandar (2009) dan Guilford (1981) menjelaskan bahwa keterampilan berpikir kreatif meliputi lima aspek kreatif yaitu kelancaran (fluency), keluwesan (flexibility), keaslian (originality), merinci (elaboration) dan menilai (evaluation) dengan penjelasan sebagai berikut: (1) Kelancaran berpikir (fluency of thinking). Pada aspek itu, maka kelancaran adalah kemampuan untuk menghasilkan banyak ide yang keluar dari pemikiran seseorang secara cepat. Dalam kelancaran berpikir, yang ditekankan adalah kuantitas bukan kualitas. (2) Lebih lanjut, keluwesan berpikir (flexibility), adalah kemampuan untuk memproduksi sejumlah ide, jawaban-jawaban atau pertanyaan-pertanyaan yang bervariasi, dapat melihat suatu masalah dari sudut pandang yang berbeda-beda, mencari alternatif atau arah. Keluwesan berpikir adalah kemampuan untuk memproduksi sejumlah ide, jawabanjawaban atau pertanyaan-pertanyaan yang bervariasi, dapat melihat suatu masalah dari sudut pandang yang berbeda-beda, mencari alternatif atau arah yang berbeda-beda, serta mampu menggunakan bermacam-macam pendekatan atau cara pemikiran. Orang yang kreatif adalah orang yang luwes dalam berpikir. Peserta didik dengan mudah dapat meninggalkan cara berpikir lama dan menggantikannya dengan cara berpikir yang baru, berpikir luwes menyediakan ruang untuk perubahan ide-ide dan berpikir untuk memasukkan berbagai sudut pandang, berbagai pendekatan berbeda dari sebuah solusi. (3) Selain itu, komponen berpikir kreatif adalah keaslian (originality). Keaslian merupakan kemampuan untuk mencetuskan gagasan unik atau kemampuan untuk mencetuskan gagasan asli. Keaslian berkaitan dengan kemampuan memberikan sesuatu yang kas atau unik yang berbeda dari yang lainnya. Keaslian adalah kemampuan untuk membuat kombinasi-kombinasi yang unik dari suatu pemecahan masalah. Keaslian ide digambarkan sebagai sesuatu hal yang unik mengejutkan, tidak biasa, tidak konvensional, aneh, dan luar biasa. (4) Aspek merinci (elaboration) pada berpikir kreatif dititik beratkan pada kemampuan dalam mengembangkan gagasan dan menambahkan atau memperinci detail-detail dari suatu objek, gagasan atau situasi sehingga menjadi lebih menarik. Dapat juga dikatakan elaborasi merupakan penambahan detail atau keterangan terhadap ide yang sudah ada. Dan (5) Aspek terakhir yang menjadi titik kritis berpikir kreatif adalah evaluasi (evaluation). Aspek evaluasi merupakan kemampuan untuk mengambil keputusan terhadap situasi yang terbuka. Evaluasi dalam memecahkan suatu masalah tidak hanya mencetuskan gagasan tetapi juga harus melaksanakannya dengan arif dan bijaksana. Dalam meningkatkan kemampuan berpikir kreatif dan penguasaan konsep kognitif itulah menjadi sangat penting pengembangan model pembembelajaran OPPEMEI menjadi sangat penting.

Model OPPEMEI merupakan salah satu model pembelajaran untuk meningkatkan kreativitas peserta didik. Sehingga partisipasi differensial akan terlihat nyata. Partisipasi differensial dapat menggambarkan dan 
menjelaskan penyebab mendasar dari tingkat partisipasi diferensial dalam bidang-bidang tertentu, dan kami mendiskusikan arah utama untuk penelitian di masa depan (Demontis, D. et al., 2019). Model pembelajaran OPPEMEI diekstrak dari tiga model pembelajaran inovatif berpusat pada mahasiswa seperti PBL, BBL dan inquiri. Formulasi berpikir kreatif peserta didik merupakan inti yang dikembangkan dari model OPPEMEI. Kondisi ini didasari bahwa model pembelajaran untuk sains selalu berangkat pada model pembelajaran 5M (Mengamati, Menanya, Mencoba, Menalar, dan Mengkomunikasikan). Oleh karena Model pembelajaran yang mampu menghasilkan berpikir kreatif sesungguhnya adalah penerapan pendekatan pembelajaran saintifik, meniscayakan kehadiran guru yang tidak saja sabar dan telaten, tetapi juga cerdas dan kreatif berkolaborasi dengan peserta didik untuk menciptakan kondisi pembelajaran yang memunginkan mereka mampu merumuskan masalah dengan baik. Para guru/dosen diharapkan mampu menfasilitasi peserta didik berlatih berfikir analitis, bukan berpikir mekanis. Pendekatan saintifik juga terlihat pada tahapan Model OPPEMEI yang terdiri : (1) orientasi, (2) penggalian ide kreatif, (3) penyelidikan (investigasi), (4) elaborasi, (5) menyajikan hasil karya, (6) evaluasi, dan (7) implementasi. Penggunaan model ini berangkat dari teori motivasi kognisi, teori ini percaya bahwa individu terdorong untuk melaksanakan tindakan dari pemikirannya bila diberikan stimulus dengan berbagai masalah yang kontekstual, sehingga terkonstruksi pemahaman yang lebih mendalam. Selain itu kontruksi keterampilan berpikir kreatif juga dapat dimunculkan dengan baik.

Selain itu, karakteristik model OPPEMEI meliputi : (a) Keluwesan dapat dilakukan dengan memberikan orientasi terstruktur pada peserta didik, sehingga memberikan stimulus pada kinerja otaknya, untuk dapat berpikir asosiasi sehingga melahirkan ide-ide baru, yang merupakan produk berpikir kreatif. (b) Kebaruan ide, pada kemampuan berpikir peserta didik, membutuhkan ruang untuk menggali ide-ide baru. Ide-ide baru dapat terjadi apabila memberikan sebuah permasalahan, sehingga menghasilkan kondisi konflik kognitif pada diri peserta didik, (c) Setelah memperoleh ide/gagasan dibutuhkan pengujian untuk memperoleh data dengan melakukan penyelidikan. (d) Munculnya ide baru, yang merupakan hasil dari berpikir kreatif membutuhkan kondisi untuk peserta didik mengolah masukan ide dari berbagai sumber, kondisi ini membutuhkan fase elaborasi pada tahap pembelajaran, (e) Hasil dari penyelidikan memerlukan tahap untuk menyajikan hasil karya, (f) Ide gagasan yang disajikan membutuhkan evaluasi, sehingga ada umpan balik untuk memantapkan ide/gagasan, yang dihasilkan dari proses berpikir kreatif. (g) Masukan-masukan yang didapat membutuhkan penguatan, sehingga membutuhkan pengintegrasian untuk diimplementasikan agar terjadi proses internalisasi pada diri peserta didik.

Kebaruan model OPPEMEI dibandingkan model pembelajaran model Inovatif dan kreatif lainnya adalah (1) dapat membangun kemampuan untuk berpikir lancar (fluency), sehingga terfokus dan meningkatkan rasa ingin tahu dan senang dalam memecahkan masalah sains, (2) Peserta didik dapat memiliki motivasi intrinsik secara tepat serta rasa percaya diri dalam proses pembelajaran, (3) Membangun cara berpikir original (asli) dalam menyelidiki suatu permasalahan, sehingga mudah merumuskan hipotesis serta pikiran terbuka terhadap berbagai situasi serta mampu membuat gambaran mental terhadap masalah yang dihadapi, (4) Mengembangkan dan memperluas suatu gagasan baru (originalitas), serta dapat menjelaskan secara rinci /mendetail serta mampu memberikan argumentasi ilmiah dengan mengkonstruksi teori dari berbagai sumber pengetahuan, (5) Mahasiswa memiliki kemampuan berpikir yang luwes untuk mempertahankan dan menerima pendapat. (6) Mahasiswa mampu mengoptimal penguasaan konsep dan kemampuan berpikir kreatif nya, sehingga melahirkan rasa senang dan mencintai proses belajar pada diri mahasiswa. (7) Mahasiswa mampu menilai dan membuat masalah baru setelah melaksanankan pembelajaran.

Hasil pengembangan model pembelajaran OPPEMEI berupa model pembelajaran yang menggunakan berbagai strategi dan tahapan dalam membangun konstruksi keterampilan berpikir kreatif pembelajaran. Model OPPEMEI dapat memberikan ruang gerak untuk pencapaian standar kompetensi lulusan, yang mencakup sikap, pengetahuan, dan keterampilan yang menjadi prasyarat minimal lulusan perguruan tinggi, dengan menitik beratkan pada aspek kreativias, sehingga lulusan memiliki konsep teoritis bagian khusus dalam bidang pengetahuan dan keterampilan tersebut secara mendalam.

Beberapa argumentasi ilmiah model OPPEMEI dapat menunjang kompetensi lulusan dapat diuraikan sebagai berikut. 1) Pada fase orientasi, mahasiswa dituntut dan dikondisikan untuk memiliki kemampuan berpikir lancar (fluency), sehingga terfokus dan dapat meningkatkan rasa ingin tahu dan senang dalam memecahkan masalah sains. Berpikir lancar dapat diinisiasi dalam dua persoalan, yaitu isyarat kelancaran digunakan untuk memantau awal: kelancaran menjawab, atau kecepatan yang menghasilkan jawaban awal, intuitif (Thompson, Prowse Turner, \& Pennycook, 2011), dan kelancaran perseptual, atau kemudahan masalah yang dapat dibaca (Alter, Oppenheimer, Epley, \& Eyre, 2007, dalam Thompson, V. A., et al., 2013). Solusi kelebihan fase orientasi dibandingkan dengan model trivial awalnya adalah pada aspek pemberian contoh lebih sederhana, untuk menyerderhanakan permasalahan. 2) Fase kedua, penggalian ide kreatif; mahasiswa pada fase ini menggali ide-ide kreatif dalam memecahkan masalah dengan membuat rumusan masalah, rumusan hipotesis, menentukan variabel, definisi varibel, dan merancang prosedur eksperimen. Mahasiswa dapat belajar secara optimal, bila dosen memberikan motivasi intrinsik secara tepat (Chou, 2007). Peserta didik diberikan masalah 
bersifat ambivalensi/ill structure, maka akan meningkatkan rasa ingin tahu (Arends, 2012:405). Solusi dari mengatasi kelemahan pada model BBL, PBL dan Inkuiri, pada fase ini mahasiswa dapat membangun konsep belajar terintegrasi dan pemahaman yang menyeluruh. 3) Fase ketiga, penyelidikan/investigasi. Dosen mendampingi mahasiswa melakukan penyelidikan/investigasi sesuai dengan desain rancangan yang telah ditetapkan. Mendampingi mahasiswa untuk mengklasifikasikan data dan fakta yang diperoleh secara runtut. Solusi yang diperbaiki adalah mahasiswa dapat menentukan cara yang paling baik dalam pemecahan masalah sains dalam kelompok yang tidak besar. Mahasiswa memiliki pikiran terbuka terhadap berbagai situasi serta mampu membuat gambaran mental terhadap masalah yang dihadapi. 4) Fase keempat, elaborasi, mengembangkan dan memperluas suatu gagasan baru (originalitas), memperinci detail-detail pemecahan masalah dan argumentasi ilmiah yang termuat dalam laporan hasil penyelidikan. Dukungan Empiris Penyediaan lingkungan belajar yang sesuai dengan kebutuhan anak didik (Amabile \& Hennessey, 1992; Hasirci \& Demirkan, 2003;) Solusi dalam mengatasi kelamahan pada model PBL, BBL dan inkuiri, yaitu dengan modifikasi pada fase elaborasi dengan meningkatkan nilai kerjasama, kegiatan memberikan waktu lenih lama dengan karakter kelompok yang bersifat heterogen. Pada aspek pemecahan masalah diberikan lebih rinci, sehingga mampu meningkatkan berpikir tingkat tinggi pada peserta didik. 5) Fase kelima, menyajikan hasil karya, mahasiswa mampu berpikir lancar untuk menghasilkan banyak gagasan/jawaban yang relevan dengan permasalahan sains yang diberikan dan memiliki kemampuan berpikir yang luwes untuk mempertahankan dan menerima pendapat. Mahasiswa mampu mengungkapkan gagasan/gambaran pengalaman hasil penyelidikan secara rinci. Solusi yang diberikan pada fase ini, yakni membutuhkan pedampingan dengan managemen waktu yang ketat. Mahasiswa mampu dengan lancar mempersentasikan hasil penyelidikannya. 6) Fase keenam evaluasi, pada fase ini mahasiswa dapat menilai situasi yang berkaitan dengan pemecahan masalah. Mahasiswa mampu mengevaluasi hasil pembelajaran secara proses dan produk. Solusi yang ditawarkan. Membutuhkan rubrik untuk penilaian, Dapat menjadi inspirasi bagi IQ Tinggi dan Rendah. 7) Fase ketujuh implemetasi, mahasiswa mampu secara originalitas menerapkan teori/konsep untuk menghasilkan produk kreatif, serta mahasiswa mampu reflex (evaluasi) dan penilaian akhir atas keterampilan berpikir kreatif, sehingga mahasiswa mendapatkan pengetahuan yang signifikan. Solusi yang sodorkan pada fase ini, yaitu dibutuhkan pengajar yang mampu mengimplementasikan ide-ide yang baru dalam kehidupan sehari-hari. Mengoptimalkan penguasaan konsep dan kemampuan berpikir kreatif, sehingga melahirkan rasa senang dan mencintai proses belajar.

Hasil lebih lanjut disajikan dan implikasinya dibahas (Puccio, G. J., et al., 2018). Terungkap bahwa dalam menyelidiki suatu permasalahan, sehingga mudah merumuskan hipotesis serta pikiran terbuka terhadap berbagai situasi serta mampu membuat gambaran mental terhadap masalah yang dihadapi. Oleh karena itu, sejak zaman dahulu, orang-orang sukses menggunakan "gambaran mental" dan "praktek latihan" untuk meraih kesuksesan. Napoleon, contohnya, "berlatih" berperang dalam imajinasinya selama bertahun-tahun sebelum ia benar-benar maju berperang. Dia membayangkan dirinya dengan jelas sebagai pemimpin, dan menggambarkan peta dimana ia akan mempraktekkan pertahanan. Dia membuat semua perhitungan matematisnya dalam pikiran. Ada semacam mekanisme otomatis dalam diri pembelajaran Dr. Maltz dalam buku berjudul Psycho-Cybernetics yang pertama kali dipublikasikan tahun 1960, menyebutnya "mekanisme-servo". Yaitu sebuah mesin pencari tujuan yang otomatis, yang "menyetir" jalannya ke arah target atau tujuan. Kita semua memiliki mekanisme ini dalam diri kita dan bisa menggunakannya untuk mencapai tujuan yang ingin kita raih. Mekanisme-servo bekerja seperti rudal yang di pandu. Tetapi seperti rudal yang dipandu, ia membutuhkan pemrograman yang tepat untuk mencapai targetnya. Pemrograman ini muncul dalam bentuk gambaran-gambaran mental yang kita berikan pada mekanisme-servo.

Oleh karena itu dengan model pembelajaran OPPEMEI, menunjukkan bahwa Apabila kita terus memberikan mekanisme-servo gambaran yang jelas dan tepat tentang tujuan-tujuan yang ingin kita raih, alam bawah sadar kita akan melakukan hal-hal yang membantu kita mendapatnya secara otomatis. Di sisi lain, jika kita terus berpikir dan menggambarkan hal-hal yang tidak kita harapkan, mekanisme-servo kita akan melihat gambaran tersebut sebagai tujuan kita dan berusaha untuk membuat gambaran jelek tersebut menjadi kenyataan. Mekanisme-servo bekerja secara otomatis. Ia hanya mengambil gambaran mental yang kita berikan dan mencoba membuatnya menjadi kenyataan. Ia tidak peduli apakah gambaran mental tersebut merupakan kepentingan utama kita atau bukan. Ia hanya bereaksi terhadap gambaran mental yang kita berikan. Apabila kita terus memberikan mekanisme-servo gambaran yang jelas dan tepat tentang tujuan-tujuan yang ingin kita raih, alam bawah sadar kita akan melakukan hal-hal yang membantu kita mendapatnya secara otomatis, di sisi lain, jika kita terus berpikir dan menggambarkan hal-hal yang tidak kita harapkan, mekanisme-servo kita akan melihat gambaran tersebut sebagai tujuan kita dan berusaha untuk membuat gambaran jelek tersebut menjadi kenyataan. Mekanisme-servo bekerja secara otomatis. Ia hanya mengambil gambaran mental yang kita berikan dan mencoba membuatnya menjadi kenyataan. Ia tidak peduli apakah gambaran mental tersebut merupakan kepentingan utama kita atau bukan. Ia hanya bereaksi terhadap gambaran mental yang kita berikan. 
Berdasarkan jabaran tersebut dapat dikatakan bahwa, model OPEMEI dapat meningkatkan kemampuan berpikir kreatif yang nantinya akan mempengaruhi hasil belajar mahasiswa. Model ini dapat meningkatkan berpikir kreatif karena sintaks model ini mampu mengembangkan komponen-komponen berfikir kreatif seperti kelancaran, keluwesan, keaslian, elaborasi dan evaluasi. Model OPPEMEI juga dalah salah satu model yang mampu meningkatkan rasa ingin tahu, serta motivasi mahasiswa untuk melakukan apa yang ingin dilakukan serta mempertahankan motivasi kerja. Dengan hal ini Model OPPEMEI bisa digunakan sebagai salah satu alternative dalam proses pembelajaran khususnya dalam penggunaan model pembelajaran.

\section{Simpulan dan Saran}

Berdasarkan hasil peneitian yang dilakukan dapat disimpulkan bahwa model OPPEMEI efektive digunakan untuk meningkatkan kemapuan berfikir kreatif hal ini terlihat dari hasil penelitian menunjukkan bahwa peningkatan rata-rata $\mathrm{N}$-gains dari kemampuan berpikir kreatif, sebesar $0,27,0,153$ dan 0,101 , peningkatan terjadi pada kelas F. Indikator keterampilan berpikir kreatif yang paling tinggi adalah fluency, atau kelancaran $\mathrm{N}$-gain sebesar 0,67 dengan kriteria sangat tinggi mahasiswa berpikir lancar dengan materi dan perubahannya dalam bentuk model gunung meletus. Hal ini menunjukkan bahwa model pembelajaran OPPEMEI meningkatkan kemampuan berpikir kreatif yang nantinya akan mempengaruhi hasil belajar mahasiswa. Dengan adanya model OPEMEI ini akan menjadi salah satu solusi dalam proses pembelajaran khususnya dalam penggunaan model pembelajaran. Berdasarkan hal tersebut dapat disarankan kepada pendidik menggunakan model OPPEMEI ini untuk mengembangkan pembelajaran. Karena model ini sudah terbukti dapat meningkatkan kemampuan berfikir kreatif yang mana kemampuan ini secara tidak langsung dapat meningkatkan hasil belajar.

\section{Daftar Pustaka}

Adele L. Schmidt, (2010). The Battle for creativity: Frontier in science and science education. Bioessays 32 : 1016-1019.Anderson, dkk. (Eds) A Taxonomy of Learning, Teaching, and Assessing, Revision of Bloom's Taxonomy of Educationnal Objectivees, New York: Longman.

Agustiana. T. I G.A. (2015). Model Pembelajaran Opemes dalam meningkatkan Keterampilan Berpikir Kreatif Mahasiswa PGSD. Makalah. Diselenggarakan Program Studi Pendidikan Sains Program Pascasarjana Universitas Negeri Surabaya. Surabaya: Prosiding Seminar Nasional Pendidikan Sains. ISBN: 978-60272071-0-3. Hal. 1423-1433.

Agustiana. T. I G.A, Rudiana Agustini), Muslimin Ibrahim (2015) Effect Of Brain Based Learning Model To Ability Of Concepts And Creative Thinking Skills For Students Base On Ability Of Science For Student Of Department Elementary School Of Education" in Proceeding “ ICIRAD The 1 st International Covferencence On Innovative Research Across Disciplines 2015, Kuta Bali Nopember $18-19^{\text {th }}, 2015$.

Akkuzu, N. \& Uyulgan, M.A., 2016. An epistemological inquiry into organic chemistry education: exploration of undergraduate students' conceptual understanding of functional groups. Chem. Educ. Res. Pract., 17(1), pp.36-57. Available at: http://xlink.rsc.org/?DOI=C5RP00128E.

Amabile, T. M., \& Hennessey, B. A. (1992). The motivation for creativity in children. Achievement and motivation: A social-developmental perspective, 54-74.

Arends, R. I. 2012. Learning to teach. 9th Edition New York: McGraw-Hill Companies.

Barrouillet, P., 2015. Theories of cognitive development: From Piaget to today. Developmental Review, 38, pp.112.

Blass, L., Williams, J. \& Robinson, A., 2016. 21st Century Reading 4 : Creative Thinking and Reading with TED Talks. , 20(2), pp.20-22.

Çam, A. \& Geban, Ö., 2017. Effectiveness of case-based learning instruction on pre-service teachers' chemistry motivation and attitudes toward chemistry. Research in Science \& Technological Education, 35(1), pp.74-87. Available at: https://www.tandfonline.com/doi/full/10.1080/02635143.2016.1248927.

Casagrand, J. \& Semsar, K., 2017. Redesigning a course to help students achieve higher-order cognitive thinking skills: from goals and mechanics to student outcomes. Advances in Physiology Educatio.

Depdiknas, 2005. Rencana Strategis Departemen Pendidikan Nasional Tahun 2005-2009. Jakarta: Depdiknas. 
Demontis, D., Walters, R. K., Martin, J., Mattheisen, M., Als, T. D., Agerbo, E., ... \& Cerrato, F. (2019). Discovery of the first genome-wide significant risk loci for attention deficit/hyperactivity disorder. Nature genetics, 51(1), 63-75.

Evans, James R. (1991). Creative Thinking in the Decision and Management Sciences. Cincinnati: SouthWestern Publishing Co. Evertson, C.M. Emmer, E.T \& Worsham, M.. (2003). Classroom management for elementary teachers, (6th Edition) Boston: Allyn and Bacon. Pp-12-14

Fadillah, A. E. (2013). Stres dan motivasi belajar pada mahasiswa psikologi universitas mulawarman yang sedang menyusun skripsi. E-Journal Psikologi, 1(3), 254-267.

Fang, Z. et al., 2016. National Culture, Creativity, and Productivity: What's the Relationship with Student Achievement? Creativity Research Journal, 28(4), pp.395-406. Available at: https://www.tandfonline. com/doi/full/10.1080/10400419.2016.1229976.

Gabel, D. (1998). The complexity of chemistry and implications for teaching. International handbook of science education, 1, 233-248.

Gencosman, T., \& Doğru, M. (2012). Effect of student teams-achievement divisions technique used in science and technology education on self-efficacy, test anxiety and academic achievement. Journal of Baltic Science Education, 11(1), 43.

Guilford, J.P. (1981). Way beyond the IQ. Creative Education Foundation. ISBN 0930222016

Haack, J.A. \& Hutchison, J.E., 2016. Green Chemistry Education: 25 Years of Progress and 25 Years Ahead. ACS Sustainable Chemistry \& Engineering, 4(11), pp.5889-5896. Available at: http://pubs.acs.org/doi/abs/10.1021/acssuschemeng.6b02069.

Hagger, M.S. \& Chatzisarantis, N.L.D., 2016. The Trans-Contextual Model of Autonomous Motivation in Education: Conceptual and Empirical Issues and Meta-Analysis. Review of Educational Research, 86(2), pp.360-407. Available at: http://rer.sagepub.com/cgi/doi/10.3102/0034654315585005.

Hasirci, D., \& Demirkan, H. (2003). Creativity in Learning Environments: The Case of Two Sixth Grade Art-Rooms. The Journal of Creative Behavior, 37(1), 17-41.

Hawkes, G. (1996). Sociology of sex and sexuality. McGraw-Hill Education (UK).

Chou, C. T., \& Fu, L. C. (2007). Ships on real-time rendering dynamic ocean applied in 6-dof platform motion simulator. In CACS International Conference (Vol. 3, No. 7).

Jatmiko, B., Prahani, B. K., Munasir, S., Wicaksono, I., Erlina, N., \& Pandiangan, P. (2018). The comparison of OR-IPA teaching model and problem based learning model effectiveness to improve critical thinking skills of pre-service physics teachers. Journal of Baltic Science Education, 17(2), 300.

Marinacci, M. (1996). Decomposition and representation of coalitional games. Mathematics of Operations Research, 21(4), 1000-1015.

Munandar Utami. (2009). Pengembangan Kreativitas Anak Berbakat. Jakarta: PT Gramedia Utama.

Peleg, R. et al., 2009. Proof -Teachers' views on implementing storytelling as a way to motivate inquiry learning in high-school chemistry teaching. Chemistry Education Research and Practice, 24(1), pp.61-65.

Puccio, G. J., Burnett, C., Acar, S., Yudess, J. A., Holinger, M., \& Cabra, J. F. (2018). Creative problem solving in small groups: the effects of creativity training on idea generation, solution creativity, and leadership effectiveness. The Journal of Creative Behavior.

Sadler, P. \& Sonnert, G., 2016. Understanding Misconceptions - Teaching and Learning in Middle School Physical Science. American Educator, pp.26-32.

Sener, N., \& Tas, E. (2017). Developing Achievement Test: A Research for Assessment of 5th Grade Biology Subject. Journal of Education and Learning, 6(2), 254-271.

Suyidno, N. M., Yuanita, L., Prahani, BK, and Jatmiko, B.(2018). Effectiveness of creative responsibility based teaching (CRBT) model on basic physics learning to increase student's scientific creativity and responsibility. Journal of Baltic Science Education, 17(1), 136-151.

Suzan,Z., Nana Kohn, Pao.K., Friedman, 2013, Critical Thinking of Registereed Nurses, in a Fellowship Program, The Journal of Continuing Education in Nursing Vol 44, No. 8. 
Talanquer, V., 2013. Chemistry education: Ten facets to shape Us. Journal of Chemical Education, 90(7), pp.832-838.

Thomas, Cl, 1993, Taber's Cyclopedia Medical, Dictionary, Phildelpia,: F.A.Davis

Thompson, V. A., Turner, J. A. P., \& Pennycook, G. (2011). Intuition, reason, and metacognition. Cognitive psychology, 63(3), 107-140.

Thompson, G., \& Bennett, J. (2013). Science teaching and learning activities and students' engagement in science. International Journal of Science Education, 35(8), 1325-1343.

Wahyuni, A. (2017). Analisis Hambatan Belajar Mahasiswa Pada Mata Kuliah Kalkulus Dasar. JNPM (Jurnal Nasional Pendidikan Matematika), 1(1), 10-23.

Yu, M.-L., Brown, T. \& Farnworth, L., 2017. Embracing international students in occupational therapy higher education in Australia: Challenge or asset? Australian Occupational Therapy Journal, (March). Available at: http://doi.wiley.com/10.1111/1440-1630.12389.

Yuriev, E., Capuano, B. \& Short, J.L., 2016. Crossword puzzles for chemistry education: learning goals beyond vocabulary. Chem. Educ. Res. Pract., 17(3), pp.532-554. Available at: http://xlink.rsc.org/?DOI= C6RP00018E. 